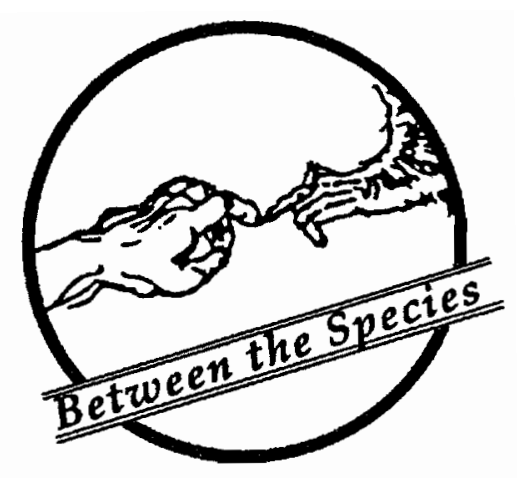

\title{
Autobiography of a Revolutionary
}

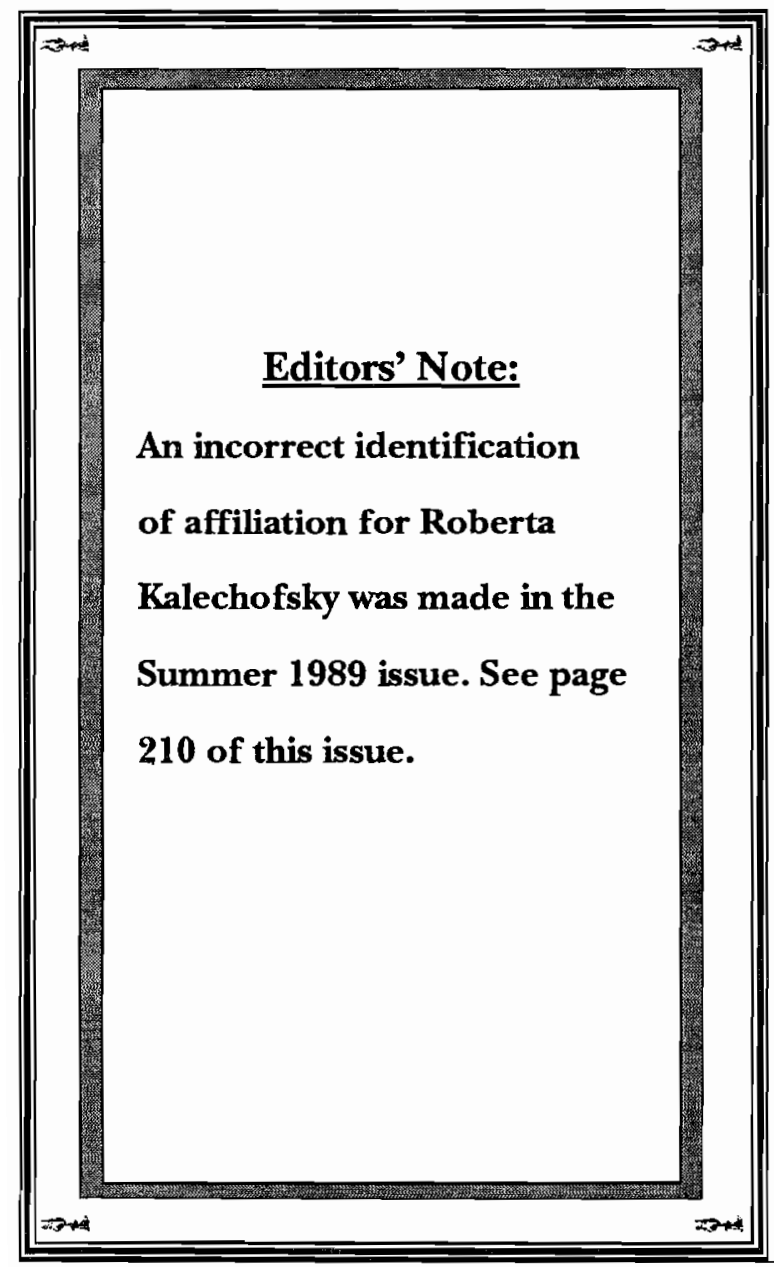

Fall 1989
Roberta Kalechofsky Jews for Animal Rights

y membership in the Animal Rights Movement was unpredictable. I did not join the movement. I was catapulted into it. I did not go looking for it. I did not know it existed. I turned a page in a book, I turned a corner in the universe and was confronted with a terrible evil. But now I know, and my life has changed. An immense detour in myself, foremost as a writer, has developed. I ache for my old themes, the material of Jewish-Christian relations I explored in Bodmin, or the first five centuries of Christianity I had come to know so well I could itemize the goods lying on the wharves of Ostia where slaves and animals for the gladiatorial

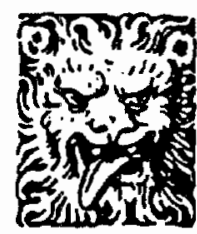

(C) Roberta Kalechofsky, 1989

AUTOBIOGRAPHY 
combats disembarked from foreign shores, to die for the entertainment of an over-ripe civilization. I worry about whether I will ever again have time to write about these themes and ages, the centuries which formed my first notions of barbarity, of cruelties in well-worn traditions. Ah! the blessings of an historical framework, even for barbarism.

The 20th century is hard on writers. It has depleted our stock of language about evil. Ernest Hemingway turned his back on language after the first World War; George Steiner wrote his elegy on language after the Holocaust. Time and again, I think how useful "anti-Christ" (as the antithesis to good) was to Christian medieval writers. I need a word to describe "Unnecessary Fuss" as the polarization of whatever I might mean by God. Blasphemy, like evil, is in the dustbin.

When the cultural force of a word dies, a dictionary definition might be useful, except that my Oxford Universal Dictionary defines "evil" as "A. adj. the antithesis of Good. Now little used, except in literary English." Is it then a term used only be archaic writers? Is so, what word shall 20 th century writers use to denote the dismantling of the universe as known by atavistic believers in a creative force once called God, called Ya-wha, called shaping Genius, Source of breath and soul-stuff, called life-force, called teleology, called Providential, called covenantal, called the Promise-Never-to-Destroy-Again, called the-Voice-in-the-Whirlwind, in-the-thunder, fromthe-mountain, called Father-of-Mercies, called IWho-will-be-with-you-always. Yes?

I grew up in a patchwork of traditions and beliefs, lucky to survive the crush of contradictions in my family and in my culture. Animals had little to do with the first thirty-five years of my life, so that it is a marvel that they now have everything to do with the Jewish upbringing I had the first ten years of my life. My parents were separated when I was a year old, my mother an aspiring modern Jew, my father the only son of Orthodox Jews who regarded modernity as one more phase to be tolerated and ignored in the history of the Jewish people. Real history was the line of development from God to Adam and Eve to the generations of Abraham, Isaac and Jacob, to Moses, to me. The rest were passing fancies. I never heard of Darwin until I got to college. In place of "knowledge" I was raised to believe that God knew everything I did, and everything I did mattered. That impression of a direct line between me and God faded as I matured, but enough remained so that when it was evident that my husband and I were going to marry (there was no formal declaration of this, just a sliding towards inevitability), I told him that if he was going to marry me, he should be prepared to know that I had a destiny to fulfill. He asked me if I knew what it was. When I told him I didn't, he shrugged his shoulders and decided to take his chances anyway. He did not know what I was talking about. Neither did I.

The years that were responsible for this peculiar slant were spent in a partly rural neighborhood of Brooklyn, populated by Christians and Jews from Eastern Europe, Polish Catholics and Russian Orthodox Slavs with Mongolian faces. Summer nights, in the democracy of heat, everyone sat outside on folding chairs and gossiped. Summer nights, too, we were periodically invaded by a menace, the equivalents of Skinheads, who would set bonfires on nearby empty lots and perform rituals I was forbidden to watch.

Milk and fruit and vegetables were delivered by horse-drawn carts. (True mechanization did not begin until after the second World War.) Some people kept goats or a few chickens in their backyards. When the animals were killed, I did not see it. I did not go to the slaughterhouses which were small, local places at the time. When my grandmother brought home a dead chicken and placed it on her lap to pluck its feathers, I did not relate it to living ones. The act of violent death was secret to me, the dead and the living separate creatures, until one night I bit into the forbidden apple and went where I was told not to go. I stole out of the circle of night gossipers to watch this other human race from another world at their bonfire rituals, racing dogs and daring one another to leap over the flames they had made. The night crackled with a contagious violence. The dogs on their leashes went wild with frenzy when a kitten was caught, was bound by her paws to a spit, and placed over a bonfire to burn.

I have a memory of not feeling anything, except that I should report "this thing" at once - I was definitely not grown-up enough to deal 
with it. I have a memory of myself running back, confidently, to the circle of grown-ups sitting in the shadow of the trees, to deliver my report, with a curious primness about how I went about the business of reporting evil. Directly - as I had been told to do. Opening my mouth. Saying: "Dear Editor, I wish to report an evil in my neighborhood. Surely, you will print my letter, and inform the world." There was a pause in the gossip, nothing more. Only the breezes stirred. The sounds that remained of the incident were the mewing of the kitten and the frenzied barking of a dog. I did not know then that I was witnessing a common ritual in brutality, unpretentious in its mechanism, no supporting vested interests, no class conflicts, no ideology, no religious motivations; most likely rooted in the need to master death by becoming a technician of the process, practiced by those to whom death is an obsession; and that the reactions of those to whom I delivered my report were equally commonplace, the hiatus in conscience through which history flows.

A dozen years went by before I thought about that incident again. I had become a writer, selfconsciously, with the objective of being published, being read, becoming famous, writing prose that would do what I wanted it to do change the world. I did not want my writing to reflect it, to "hold the mirror up to nature." I wanted to re-write history, smash the mirror and put it back together again in language that would compel change. I could not recover from Eden. I was hopelessly naive.

The first story of mine to be published dealt with this early incident. It was called "To Light a Candle" - a mawkish title - in which the observer of the night's auto da fe holds her finger in a candle flame to experience the flame, to identify with the victim. Motivation unknown.

The world changed. The small, rural neighborhood disappeared into concrete and highrises. Horse-drawn wagons, backyard goats and chickens disappeared. I never saw animals again except when we "went to the country," a momentous excursion in the era before thruways and super highways. I formed a love of nature, of clouds, of climate, of oceans and mountains, rainfall, wind, the rhythm of seasons and growing things, the response of adolescent body to sultry night. It was a nature devoid of animals, except for an occasional muzzled bulldog terrier (favorite breed at the time). Cows in a country field terrified me. I couldn't tell them from the bull, and the bull had a bad reputation. Animals belonged in cages or in books or on a leash. I did not know they existed in any other way. Tarzan and Cheetah were a myth. Sundays were spent desultorily in parks and zoos with my father, whose visiting rights entitled him to that, and me to throwing peanuts at the elephants and watching the monkeys masturbate.

This prolonged ignorance about animal life began to disappear when my husband taught me how not to fear dogs. Being a jogger and a biker, I was made miserable by dogs who ran after me. My husband taught me how to talk to them. Instructed that almost any dog I would meet on a city street would most likely be domesticated, I learned how to say sternly, "Go home". - the only two words I knew in their language, but they worked. To me, they worked like a miracle. Dogs wagged their tails and trotted away. (This technique does not work with rapists.) Dogs, I learned, were sociable creatures. They understood language in a context. My next step was to pat the dogs I spoke to. Friendliness became an open sesame to the animal world. The dogs along my jogging route became part of my landscape of nature, the gardens and early morning sunlight I loved to see.

A friend once asked me where I got my love of nature. I told him from the Bible, but after I left my grandparents to live with my mother, around the age of ten, I no longer lived in "Bible time," but in a "fashionable" neighborhood, remote in sentiment and social habits from my grandparents'.

In my senior year at college I took a course in the Bible more out of curiosity than loyalty. We read Genesis, the prophets, Psalms, the Book of $J o b$, and parts of the New Testament. Professor Rypins told us, in his introductory lecture, that we were the first class in the entire country to take a course in Bible literature at a secular college, and that he had struggled for twenty years to have such a course included in the curriculum. He beamed with satisfaction and said, 


\section{"You are all revolutionaries."}

I do not know why the others were there; my motives were desultory, and I did not feel entitled to his praise. Nor could I share his enviable love for the Book of Job which, he told us, sustained him through many vicissitudes. I looked forward to sharing this sustenance - I could use help - but received a shock when I realized I was on the wrong side of the argument: I identified with the counselors and not at all with Job. Educated in commonsense thinking, their arguments seemed reasonable to me compared with Job's accusations or with God's response to Job:

Where wast thou when I laid the

foundation of the earth?

-...

When the morning stars sang together

And all the sons of God shouted for joy.

Was this an answer to the problem of injustice and evil? I wanted to kick Job!

That same year I also took a course in Modern European Fiction. We read Gide, Kafka, Proust, and Malraux. Something in that reading diet made me sick. I was seized, internally, by incoherence and dropped out of the course, though it was a dangerous thing to do in my senior year. But I could not read about the aberrations of Baron Charlus, the muffled, oblique world of Kafka, the bloody world in Man's Fate, where violence becomes a means of psychological reification and an estheticized technique, without a sense or terror that the human race had been remade according to laws I could not recognize. I wrote a letter to my professor which said essentially, "I do not understand the 20th century and cannot read its literature."

The crisis about whether I would graduate passed. My professor charitably gave me an " $A$ " (momentary insanity is sometimes a compelling argument), but the crisis in my understanding of this century took decades. Like most Jewish children, I knew my history of anti-Semitism, blood libels and pogroms, but there was a piece of the puzzle missing for me in the documentation of the Holocaust. Why the elaborate technology? Why elaborate, massive, baroque, bureaucratized technology? Is it not simpler to kill people in their villages and ghettos, like the old-fashioned crusaders and Cossacks, than to transplant them hundreds of miles to killing centers? In place of horsemen with cruel whips was a captured photograph of a German soldier scrubbing the skin off a prisoner's back with a brush made of barbed wire. The air is still. The place is empty. Flat ground extends beyond them. The victim is almost dead, perhaps dead, for his tongue lolls loosely from his mouth. The soldier does not notice. He is very young and bored. His gaze is distant. Perhaps he is daydreaming about his girlfriend.

There is no blood lust here. Nazi honor forbade it. So, with cunning, Eichmann and others could say that he "personally" was not an anti-Semite, he "personally" had Jewish friends; his "personhood" was not involved in the machinery of execution. No parallel is intended here between the Holocaust and vivisection, between people and animals, but a common mentality embraces the vivisector who says he "personally" loves dogs, he "personally" has two or three pets at home; he "personally" hates pain and violence. He does what he does constrained by an ethic different from the "Skin-heads" of my youth. Not until I learned the history of vivisection could I understand that emotionless gaze, the divorce between act and feeling, violence without personal involvement, which is a current in the modern sensibility.

It is a new ethos, which Hitler expressed when he demanded efficiency and rationality in matters of destruction. A man of the 20th century, he distrusted emotionality and hated the archaic blood lust, the sexual excitement that races through the groin in the act of killing. He sought to "purify" the S.S. of such primitive promptings. Hannah Arendt remarked that "the concentration camps are the laboratories where changes in human nature are tested." The "technological imperative," mastered on other living creatures, had transformed our omnipresent impulse towards destruction and created a new balance between good and evil. We shall miss the old brutalities.

As with other Jewish children of my generation, the Holocaust was not a topic of conversation, except for hushed references about 
"disappeared" relatives. Before this fateful era had a name, I pieced it together by myself after my children were born, no doubt because I became a mother. Two unplanned journeys began for me the night I went into labor with my first son. The act of giving birth astonished me. Its physicality was monumental. The pain was not predicted. The process ignored me. No use to cry out, "I've changed my mind!" I woke the next morning, discovering dimensions to myself I did not know existed. I had read dozens of books about becoming a mother. None of them had prepared me for the "irrational(?)" feverish attachment I felt immediately for my son. Where had it come from? It seemed to rise from the nature of motherhood itself, a nature known to $m e$, in this first stage, only through the literature of animals, mama bears, wolves who defended their cubs with their lives, birds who shrieked to frighten an enemy from their nest, who were the paradigm for a God with "sheltering wings," the protectoress whose consuming care for her offspring is the secret of survival.

\section{Thou art my God from my mother's belly}

This identification with animal nature, when stripped of culture, is not unique. It exists beneath our socialized personalities and manifests itself when we are confronted with experiences common to animals. Prison literature often attests to the identification with the fate of animals. Irina Ratushinskaya, imprisoned by the Soviets, wrote in her collection of poetry, Beyond The Limit:

\section{We live stubbornly- \\ like a small beast \\ who's gnawed off his paw \\ to get out of the trap on three-}

Terrence Des Pres, in his absorbing effort to understand human behavior in the concentration camps (The Survivor, Oxford University Press, 1976), again and again uses studies of animal life to create a "biosocial" norm and ethic. In one instance he refers to baboons in Nairobi Park who, after having established friendships with tourists, were shot by a parasitologist; thereafter, all baboons avoided human beings in the park. The evil had been communicated to the others:
"We learn what to fear, what to call evil and therefore what to call good, by absorbing the costly experience of others....It is highly adaptive for animals to learn what to fear without having to experience events directly themselves" (p. 236).

But such connections between myself and animals were largely subliminal, until Sasha came into my life. She was the dog we adopted to atone for Dylan, whose death was caused by our carelessness. Dylan was ten years old when he died, suffocated in a parked car. We had done the "reasonable" things, left the windows open enough for air, but not enough so that he could jump out, left a bowl of water which he turned over in panic, left the car parked under a shady tree the temperature was about 83 . In the three hours we were gone, it rose unpredictably 15 degrees. Dylan died in my arms. I know how a dog looks who has been subjected to a heat experiment.

Dylan had not been a "loveable" dog. He was crotchety and jealous of babies, he loathed everyone in a uniform, postmen, policemen, firemen, and meter-maids. We called him our "counter-culture" dog. We had bought him from a kennel in the early 60 's that bred wire-haired terriers, (his mother had inadvertently mated with a beagle who had jumped the fence to get at her, and her offspring were a loss to the kennel), prodded by my son who insisted that if I were going to have a baby (I was pregnant with my second son), he was entitled to a puppy. Not wishing to tangle with this logic, we brought him home a pet and named him for the poet, Dylan Thomas (not for Bob Dylan).

He was scrappy from the day he entered our house, always getting into trouble, always getting us into trouble. Twice he bit our mailman. Once he urinated into the open suitcase of a house guest. When he was five, to our horror he jumped from the window of our car and tore the nerves in a front haunch. The leg had to be amputated. Dylan was unfazed. Three-legged, he sprang at horses and battled with Great Danes. Old people identified with his handicap and loved him. One elderly lady, who walked with a cane, conversed with him every morning, "I know just how you feel, missing a leg!" Another elderly gentleman, who had been born in Civil War Days, placed gifts of bones and leftovers for 
him in our backyard. People called us and related sad stories of how they had put a pet "down" when he had lost a leg, believing an animal could not live on three legs. Some of their stories were thirty years old. Regret and guilt re-emerged in them at the sight of Dylan. Professor White, who has done head-transplants, has described affection for animals as "a special form of insanity." this "madness" is apparently very widespread. Dylan could survive anything, except human stupidity. He became a symbol for me, as he was for our elderly neighbors, of the life instinct, uncivil when his territory was threatened, self-sufficient if left to itself. He became the dog, Aleph, in my novel, Orestes in Progress, whose nose for evil smells selfdestruction in his human masters. Animals were now not only in my landscape of nature but demanding a place in my landscape of thought.

That process became more active when Sasha gave birth to a single puppy the year after Dylan's death. We had adopted her from an acquaintance who saved stray animals on a few acres of farmland. She came looking for us. We were looking at other animals, more pedigreed ones. Twice she escaped from her cage, ran after my younger son and sat down on his toes. He pointed his ten-year-old finger at her and said, "I want this one." She had no records, no background. She had been found on a street, deserted, thrown-away, abused. She came to us out of the misalliance of humans and animals, and revealed to me the secret of God's response to Job: the ingenuity of nature, the extraordinary compatibility of form and function, the nearperfect fit between mother and offspring, the incredible design repeated through millennia, with few accidents. I would watch her sleep next to her puppy, her long white, fox-like body wrapped around her daughter, this new, knownothing ball of fur who found her way to her teats through ancient pathways. I watched how she went out for her walks, first surveying the scene where her puppy slept, so like any mother looking into a nursery before she leaves the house; how she returned and surveyed the scene again to make sure nothing had gone wrong while she was gone. I read her thoughts. They once had been my thoughts.
With respect to the emotions of joy and sorrow, and the feeling of the mother for her young, there is no difference between the human and the animal.

(Maimonides)

Through Sasha I apprehended an order in the world, faith in creation, justice in God's design. She, too, entered my writing imagination and became in Bodmin, 1349, the "mutter" from whom the heroine, Miriam, learns what I had learned and tells her estranged husband:

Her pups came out and she licked them clean and pushed them about with her tongue until they had life and began to move and found their way to her teats. She laid herself down with no more ado while I, cast out from the animal world, wandered with fear and with hunger. But I went now with peace for I saw there was law and governance in the world, and I cared no more for what others taught of the evil that be in nature and matter, and that the soul alone can lift this evil. I cared no more for what they teach for I saw that the mutter had a law that governed her. I saw that the sun and the moon and the birds and the beasts had a law though you have taught me that they have no soul, but man who has a soul has no law that governs him.

Throughout history animals have constituted categories of thought, of joy, of perspectives on human nature. "They are," as Penelope Shuttle has written in her poem, "The Animals from Underground," "the earth's hidden reserve of innocence."

Modern man also studies the birth process. The October issue of Science, 1984, describes such a study at Columbia Presbyterian Medical Center, where Dr. Raymond Stark, a pediatrician, and a team of researchers wish to explore the mystery of what triggers birth. Dr. Stark makes an incision in a monkey with a five-month-old fetus. He perforates the uterus and takes out the head of the fetus and makes an incision into its head, exposing the trachea in to which he slides a catheter that will allow him to measure the fetus' breathing. He inserts catheters into the carotid 
artery and jugular vein, then stitches the neck closed. He then twirls a tiny drill bit into the soft bone of the fetus' forehead and inserts another catheter into the cerebral-spinal fluid. Three more holes are drilled into the top of the fetus' skull for three more catheters. More catheters are placed in the fetus' neck to measure electrical activity of the heart. The fetus is now returned to the mother's uterus. All incisions are closed, except for the catheter tubes and wires from electrodes which protrude from the mother's right side. The mothers spends the next four weeks in a restraining device, so that she cannot pull out the wires. Dr. Stark has made twelve attempts with monkeys to deliver in this way. All have failed. Dr. Stark explains: "The baboons like to give birth at night when no one is around. Because of the chair, and the catheters and electrodes, they can't properly tend to the infants without help, and they die.'

Claude Bernard, the "father" of the vivisection progress, has described it as "the dismantling of the living organism." In the century since he died the techniques for doing this have become ingenious and incalculable. Not merely organs from single animals are dismantled, but whole animals are dismantled and put together according to the fancies of experimenters. The experiments are beyond ordinary imagination, and the public is ignorant, as I was, of the subterranean world that exists in basements, in "maximum security" entrenchments beneath the campuses of many large, respectable academic institutions.

Isaiah had cursed the land because its inhabitants practice the cruelty of tearing a limb from a living animal (2224:6)! This bears thinking about in relation to vivisection. No amount of casuistic evasion can obliterate the fact that in the Torah, God's covenant includes the animal world. No doubt there will be a great deal of squirming by many people before that plain fact is accepted for what it is.

I discovered this other world of "experimentation," rather than "experience," by accident. The words "animal research" had conveyed nothing more sinister to me than rats in a maze or on a treadmill. While doing research on a German-Italian novelist, Curzio Malaparte, I read his chapter entitled "The Black Wind" in his novel, Skin. It is about a man who loses his dog, and finds him in a research laboratory.

He opened a door and we entered a large, clean bright room, the floor of which was covered with blue linoleum. Along the walls, one beside the other, like beds in a children's clinic, were rows of strange cradles, shaped like cellos. In each of the cradles was a dog, lying on its back, with its stomach exposed, or its skull split, or its chest gaping open....

Suddenly I uttered a cry of terror. "Why this silence" I shouted. "What does this silence mean?"

It was a horrible silence - a vast, chilling, deathly silence, the silence of snow.

The doctor approached me with a syringe in his hand. "Before we operate on them," he said, "we cut their vocal cords."

The day before I read this passage I had seen an advertisement in a newspaper about an animal rights organization, and had thrown it out with the paper. Now I went to my garbage can, found the advertisement, and called the telephone number on it. Like so many other people, I had avoided the literature on the subject. Only a week before, I had seen of copy of Dallas Pratt's book, Alternatives to Painful Experiments on Animals, in a local library, peeped into it, and had immediately shut the book. I had said to myself, what so many others now say to me, "I can't bear to look at that." Now the material forced its way into my consciousness. It clutched me by the throat. I had thought, after I had absorbed the literature on the Holocaust, I would never again have to rebuild the world I knew. Now again, everything unravelled and had to be pieced together, had to be rethought, particularly that such evils could take place a short distance from where I lived and I could be so ignorant of them. Surrounded by friends who "were in the sciences," I was one of those anomalous creatures Alfred North Whitehead describes in Science and the Modern World, to whom science is irrelevant to their knowledge of the world. My interests lay in dramas like Oedipus $R e x$ and Job. My ignorance of science was "cute" 
and dangerous. Like Oedipus, the circle of complicity came back to me. Again, I had to relearn the 20 th century and that its chief virtue, intellectual curiosity, is our greatest danger. Intellectual lust, as Augustine knew, is more dangerous than sexual lust.

No devil at the door. No pacts sealed with wax

And dabbled with blood. Only the drone of minds

All but unhearable yet issuing these absolutes:

Perfections like traps, all the taut majesty

Of device. We pray each night that we will have

A history. We pray for all that is uninvented. (Baron Wormser, "Intellectual Beauty")

It took me several years to learn how to read material about animal research "voluntarily." In the beginning I could read only a page at a time. I hated to come across it "by surprise." I had to prepare myself and learn, step by step, how to deal with my reactions to this material. I could extrapolate from my previous ignorance of it that most Jews, like most of the public, did not know what was going on. It was also clear that the animal rights movement did not understand Judaism and that the term "Judeo-Christian" creates a harmful confusion, to the detriment of understanding the Jewish position vis a vis animals. Someone had to be a bridge between the different confusions. I did not wish that someone to be me. I was wary of creating another organization, in addition to Micah Publications, that would take me away from writing. I knew that organizations meant hours and hours of secretarial work. I said to myself, "No, no, no, no, don't do it," then sent two dozen press releases about Jews for Animal Rights to the Jewish press, dreading the erosion of time this would mean. Several weeks later I received a book of stamps from a lady (how prescient!) and a note: "God bless you for this holy work." I was hooked.

The first step towards the modern world of technological destruction was taken when
Cartesian philosophy permitted us to reduce animals to a mechanistic model:

The split between mind and body, between man's "higher" and "lower" natures, is not only a consequence but the major goal.... The spirit soars, preens, consoles itself in a freedom gained by repressing consciousness of the body and its needs. A short-hand formula for the whole of this endeavor would be: ... where the body was, there shall spirit be. Western civilization is the negation of biological reality; and unavoidably, since life and death are inextricable, the denial of death comes finally to be a denial of life.

(The Survivor, p. 243)

The term "Judeo-Christian," as used by the animal rights movement, refers to this process, but it negates the bedrock of Jewish tradition in Torah and rabbinic literature, which asserts the dignity and moral value of animal life, expressed in what may be the earliest declaration of an animal's right: "You may not muzzle the ox when it treads out the corn in the fields." Deuteronomic law declares Sabbath rest for the animals as well as for human beings (if enforced, it would destroy the factory farming system). In "The Relevance of Animal Experimentation to Roman Catholic Ethical Methodology" James Gaffney writes:

The Mosaic law does envisage animal interests, does legislate animal rights, and, to that extent, does represent animals as moral objects.... In the Wisdom literature the underlying moral finds expression in the unfortunately neglected proverb: "A righteous man has regard for the life of his beast."

(in Animal Sacrifices: Religious Perspectives on The Use of Animals in Science, ed. by Tom Regan, p. 151.)

We have before us now two texts to evaluate:

"We are entitled to believe... that we can create anew all the substances and creatures that have emerged since the beginning of things...."

(Marcellin Berthellot, chemist, 1885) 
and God's response to Job:

Does the hawk soar by your wisdom

And stretch her wings towards the south

Does the eagle mount at your command?

If not now, very certainly in the near future, the answer to that question will be "Yes." Will the morning stars sing at this creation? Or do we look forward to it with dread, knowing - to paraphrase Camus - that he who knows everything can destroy everything.

Buber commented that in the Bible the natural world is created with a blessing, but the historical world is created with a curse. It is from the historical world of injustice that Job cries out for vindication. It is with arguments from the natural world that God justifies Himself against Job's attacks, but it is against nature that we make our prolonged war; our work is cut out for a long time to come, and our siege-works are prepared, while the historical world still remains cursed. The most radical texts for our time may be the $B o o k$ of $J o b$ and that quirky, inchoate fable, "The Tower of Babel."

\section{Letters to the Editors (Continued from page 210)}

These constitute the background and the premises I used to argue that David Bleich never even once tries to give us reasons why we may eat animals and experiment upon them. Throughout his essay, he is content merely to quote "sages" and "authorities" (as he routinely refers to them) who believe abuses of animals to be justified. I began my essay by pointing out that I am troubled by words like "authority" and "official" and claimed they were disguises to lend weight to otherwise lightweight ideas. If I am snide, as Schwartz claims, it is not so much directed at the sages but at Bleich. I hold passionate opinions about animals and I am not apologetic for adopting a tone of disrespect towards a man who thinks it is necessary to eat animals and "proves" his point by saying that that is what Maimonides believed. I explained why Maimonides' view was foolish even at the time he was writing. 1 am irritated at a person (Bleich) who thinks he can show the principle of $t z^{\prime} a r$ ba'alei hayyim (cause no pain to living creatures) is not violated when animals are made to suffer for financial benefit because a "majority of rabbinic authorities" cite financial benefit as a legitimate exception.

Schwartz is so upset by my mistaking him for a "reform" Jew that he cares not a whit about the fact that my review of his book was mainly positive although entirely negative with respect to Bleich's article. (Is he in black mood because I gave his entire book only two and a half columns while devoting four columns to the much shorter article by Bleich?) I am deeply disappointed to learn, but no longer surprised now that I know he is "orthodox," that Schwartz thinks I should show more respect for Jewish scholarship - entirely ignoring the thrust of my article, instead of rebutting it. Nowhere in his meanspirited letter does Professor Schwartz try to grapple with my arguments. Instead, he smugly takes the moral high ground, rapping me on my knuckles and taking me to task for my failure to be submissively reverent towards the "greats." Swelling his chest up with pride, he announces we should not write off people like Bleich but strive to make them aware of a better worldview. He finishes off his heap of abuse upon me and his non sequiturs by asking "Well then, what should a Jew do?" and answering his own question with "Certainly not write articles with the negative assumptions and implications of Gendin." After such a tiring display of selfrighteousness at my stylistic infelicities, little wonder that Schwartz has no energy left to deal with the substance of my claims.

Schwartz seems to think I should be keeping up with all the writings he and his opponent, Bleich, are producing. He says Bleich now claims that it isn't evil to be a vegetarian. Thanks, David, I wish I had known you have undergone a change of heart because up until now I had been having trouble sleeping. Schwartz thinks I should have reviewed the 1988, not 1982, edition of his book. I reviewed the 1982 edition because that is what the editors of this journal forwarded to me for review. What have you added, Professor? What have you withdrawn? Nobody is perfect; please tell us what mistakes you corrected. Or is the "expansion" you boast of merely a matter of adding more recipes? Is my criticism of your appeal to the Talmud, together with my supporting reason, no longer applicable? If so, you could have spared us your grouchiness and pointed to the improvements in the latest edition.

- Sidney Gendin Eastern Michigan University 